\title{
Tractive efficiency of a vehicle at variable speed
}

\begin{abstract}
The paper presents the method and results of the car tractive efficiency comparative investigations. Both technical characteristics and fuel consumption values of numerous cars tested in the ECE simulated driving cycles were used as the input data. On the basis of the obtained data together with simulated tractive energy consumption the correlation between tractive efficiency and selected parameters of a vehicle were determined. The proposed method also allows indirect determination of the average engine effective efficiency of a vehicle at variable speed.
\end{abstract}

Keywords: tractive efficiency of a vehicle, engine effective efficiency, tractive energy consumption, specific energy consumption, driving schedule

\section{Sprawność napędu samochodu przy zmiennej prędkości}

\begin{abstract}
W artykule przedstawiono opis metody $i$ wyniki badań porównawczych sprawności napędu samochodów. Jako dane wyjściowe w tej metodzie wykorzystano dane techniczne oraz zużycie paliwa wielu samochodów, określone na podstawie badań stanowiskowych w cyklach jezdnych ECE. Te dane w połaczeniu z symulacja energochłonności ruchu stanowia podstawę do określenia związków między sprawnościa napędu a wybranymi parametrami samochodu. Przyjęta metoda umożliwia również pośrednio wyznaczanie średniej sprawności użytecznej silnika, pracującego przy zmiennej prędkości samochodu.

Słowa kluczowe: sprawność napędu samochodu, sprawność użyteczna silnika, energo-chłonność jednostkowa, profil prędkości
\end{abstract}

\section{Introduction}

The tractive efficiency of a vehicle is expressed by the ratio of tractive energy consumption [4] to chemical energy of the fuel supplied to the engine. The tractive energy consumption of a vehicle equals the value of power necessary to move wheels in order to overcome the motion resistance along a given distance [4]. The energy depends on particular properties of a vehicle and kinematic parameters of the driving schedule. The tractive efficiency is also expressed by the product of the engine effective efficiency and the powertrain system efficiency which equals the ratio of power input on the drive wheels to engine effective power [4].

A specific property of the car motion in the road traffic is the variable speed described by the driving schedule, i.e. speed versus time course. A particular example of this property is the urban driving schedule composed of numerous stop-and-go modules $[3,4]$. The speed variability of a vehicle has a significant influence on the engine effective efficiency as well as on the powertrain system efficiency. As a result of this variability, the transient engine efficiency changes within a wider range and is much lower than the powertrain efficiency. Therefore, the engine effective efficiency has the predominant influence on the tractive efficiency of a vehicle.

Due to the absence of methods to define the engine characteristics in unstable conditions, it is impossible to determine the engine effective efficiency solely theoretically. Threfore, some authors [1] use engine characteristics for stable conditions so as to determine fuel consumption at the variable speed which, in consequence, leads

\section{Wprowadzenie}

Sprawność napędu samochodu wyraża stosunek jego energochłonności ruchu [4] do całkowitej energii chemicznej paliwa doprowadzonego do silnika. Energochłonność ruchu samochodu jest rozumiana jako wartość zapotrzebowania energii na kołach napędzanych [4] w celu pokonania oporów ruchu na określonym odcinku przebytej drogi. Ta energia zależy od określonych właściwości samochodu i od parametrów kinematycznych profilu prędkości. Sprawność napędu wyraża także iloczyn sprawności użytecznej silnika i sprawności układu przeniesienia napędu wielkości, którą stanowi stosunek mocy na kołach napędzanych do mocy użytecznej silnika [4].

Cechą charakterystyczną ruchu samochodu w warunkach rzeczywistych jest zmienna prędkość, którą odwzorowuje profil prędkości, czyli przebieg czasowy prędkości. Szczególnym przykładem tej właściwości jest profil prędkości typowy dla jazdy miejskiej, złożony z wielu modułów oddzielonych postojami, tworzący tzw. cykl jezdny [3, 4]. Zmienność prędkości samochodu wywiera znaczący wpływ zarówno na sprawność użyteczną silnika, jak i sprawność układu przeniesienia napędu. W następstwie tej zmienności wartość chwilowa sprawności użytecznej silnika zmienia się w znacznie szerszym zakresie i jest dużo mniejsza od sprawności układu przeniesienia napędu. Stąd właśnie sprawność użyteczna silnika wywiera dominujący wpływ na sprawność napędu samochodu.

Wobec braku metody określania charakterystyki silnika dla nieustalonych warunków pracy, nie można wyznaczyć jego sprawności użytecznej wyłącznie sposobem 
to significant inaccuracies [4]. Nevertheless, papers [4, 5] present a new method of average tractive efficiency evaluation on the basis of road tests. This method includes the road fuel consumption measurements and the driving schedule parameters become recorded simultaneously to evaluate the tractive energy consumption. For the purpose of this study, the fuel consumption specified by carmakers at test bed in simulated driving cycles were used instead of the road tests.

The investigations described in this paper include the correlation between the fuel consumption and the tractive energy consumption of numerous vehicles. The testing cycles ECE - Urban and Mixed were assumed as a standard motion at the variable speed. Both the kinematic parameters of these cycles and the characteristics of various cars were used to evaluate the tractive energy consumption regarded as a main component of the vehicle energy balance [2 - 4]. The applied method also allows estimating the average engine effective efficiency which is particularly useful for comparative purposes.

\section{Definitions}

While conversing the energy in the engine and transmitting it to the drive wheels, the vehicle power-unit generates energy losses due to specified engine properties, parts of the powertrain system and power-unit operation parameters. The quantity of energy losses are indirect increased by the driving schedule [2-4] which determines, together with the motion resistance, the transient values of the resistance torque and the rotational speed of the driven wheels. The energy losses occur due to double energy conversions while:

- conversing fuel chemical energy into thermal energy as the outcome of combustion inside the cylinders,

- conversing thermal energy into mechanical work by the crankshaft assembly.

The engine effective efficiency depends on its resisting torque resulted from the motion resistance and the crankshaft rotational speed. Both values determine the engine operation point on the graph of the engine characteristics, which is further correlated with specific-fuel consumption, a quantity inversely proportional to the engine effective efficiency. Therefore, depending on the engine load imposed by the resisting torque and the crankshaft rotational speed, engine effective efficiency may change within a wide range of values [4].

The engine reaches the highest effective efficiency while driving at a constant speed and only within a narrow range of the crankshaft rotational speed. The lowest average effective efficiency occurs at a variable speed typical for the urban traffic [3, 4]. In these engine operation conditions, the engine load and rotational speed place throughout the lower values of the engine characteristics including unfavourable high values of the specific fuel consumption. By contrast, the transmission system efficiency is much higher at the variable speed and varies within a much narrower range of values [4]. Hence the engine effective efficiency exerts the main influence on the average tractive efficiency of a teoretycznym. Dlatego niektórzy autorzy [1] wykorzystują do wyznaczania zużycia paliwa przy zmiennej prędkości charakterystyki silnika dla ustalonych warunków pracy, co prowadzi do znacznych nieścisłości [4]. W pracach $[4,5]$ przedstawiono nową metodę określania średniej sprawności napędu na podstawie badań drogowych. Metoda ta obejmuje pomiar zużycia paliwa z jednoczesną rejestracją profilu prędkości, którego parametry są niezbędne do obliczania energochłonności ruchu. W badaniach przedstawionych $\mathrm{w}$ tym opracowaniu zamiast testów drogowych wykorzystano wartości zużycia paliwa określone przez producentów na podstawie badań stanowiskowych samochodów w symulowanych testowych cyklach jezdnych.

Podstawę opisywanych badań stanowią związki między zużyciem paliwa a energochłonnością ruchu wielu różnych samochodów. Jako wzorce ruchu ze zmienną prędkością przyjęto testowe cykle jezdne ECE: miejski i mieszany. Parametry kinematyczne tych cykli, łącznie z danymi fabrycznymi różnych samochodów, wykorzystano do określenia energochłonności ruchu, stanowiącej podstawowy składnik bilansu energetycznego samochodu [2 - 4]. Zastosowana metoda umożliwia również pośrednio określenie średniej sprawności użytecznej silnika, co jest szczególnie przydatne dla celów porównawczych.

\section{Definicje}

Straty energetyczne zespołu napędowego samochodu są generowane podczas przetwarzania energii w silniku i następnie podczas jej przekazywania do kół napędowych pojazdu. Zależą one od określonych właściwości silnika i elementów układu przeniesienia napędu oraz od parametrów pracy zespołu napędowego. Pośrednio zasadniczy wpływ na wartość strat wywiera realizowany profil prędkości [2 - 4], który łącznie z oporami ruchu determinuje wartości chwilowe momentu oporowego oraz prędkości kątowej kół napędzanych. Straty energetyczne silnika towarzyszą dwukrotnemu przetwarzaniu energii podczas:

- przemiany energii chemicznej paliwa na energię cieplną, w wyniku spalania w cylindrach,

- przemiany energii cieplnej poprzez układ korbowy na pracę mechaniczną.

Sprawność użyteczna silnika zależy od jego obciążenia momentem oporowym generowanego oporami ruchu i od prędkości kątowej wału korbowego. Obie te wielkości decydują o położeniu punktu pracy na charakterystyce ogólnej silnika. Temu punktowi odpowiada określona wartość jednostkowego zużycia paliwa, wielkości odwrotnie proporcjonalnej do sprawności użytecznej. Dlatego, zależnie od obciążenia silnika momentem oporowym i od prędkości obrotowej, jego sprawność użyteczna może zmieniać się w szerokim przedziale wartości [4].

Najwyższą wartość sprawności użytecznej silnik osiąga podczas jazdy ze stałą prędkością $\mathrm{i}$ to jedynie w ograniczonym, wąskim przedziale prędkości kątowej wału, a szczególnie niekorzystnie niską wartość śred- 
vehicle. For example, the average tractive efficiency does not exceed $10 \%$ in the case of a middle-class car driven in EPA Urban Cycle [4].

Since the driving schedule determines the variability of the engine and drive-line efficiency, the car tractive efficiency may be expressed only as an average value within a given distance $[3,4]$. The tractive efficiency is a complex function of several parameters.

Not only does this function depend on the driving schedule, but it also depends on other factors such as: unstable engine operation conditions, the time span of idle driving, transmission ratio stepping and losses in powertrain system [4]. In the case of a multi-module driving schedule, the average efficiency depends not only on power phases, but also on motion phases without powering and on stops, i.e. at zero engine efficiency [3, 4].

The average tractive efficiency may be determined on the basis of the vehicle energy balance equation given in a general form:

$$
\mathrm{G}_{\mathrm{L}} \mathrm{W}_{\mathrm{D}}=\frac{\mathrm{E}}{\eta}
$$

where: $\eta$ - average tractive efficiency for a completed driving schedule, including idle phases, $\mathrm{E}$ - tractive energy consumption as the total energy supplied to the drive wheels in powered phases of the driving schedule [2, 4], $\mathrm{G}_{\mathrm{L}}$ - fuel supply to the engine during the total distance travelled including idle, $\mathrm{W}_{\mathrm{D}}$ - fuel calorific value.

The left side of equation (1) expresses the energy supplied to the engine along a given distance incluging idle and stops. In practice and for comparative purposes, the fuel consumption relates to a travelled distance $\mathrm{Q}=\mathrm{G}_{\mathrm{L}} / \mathrm{L}$.

Similarly, the energy consumption relates to a travelled distance. In this case, the specific energy consumption [2, $4,6]$, i.e. tractive energy, can be conveniently expressed as a ratio:

$$
\Phi=\frac{\mathrm{E}}{\mathrm{mL}}
$$

taking equation (1) into consideration, the tractive efficiency of a vehicle is as follows:

$$
\eta=\frac{\mathrm{m} \Phi}{\mathrm{Q} \mathrm{W}_{\mathrm{D}}}
$$

where: $\mathrm{G}_{\mathrm{L}}-$ fuel consumption within a travelled distance, $\mathrm{L}$ - total travelled distance of the driving schedule, $\mathrm{m}$ - vehicle mass, Q - fuel consumption related to the travelled distance, $\Phi-$ specific tractive energy consumption.

The specific tractive energy consumption for the schedule composed of several modules is as follows [4]:

$$
\Phi=g f L_{\mathrm{N}}+\frac{\mathrm{K}}{\mathrm{m}} \vartheta \mathrm{L}_{\mathrm{N}}+\mathrm{a}
$$

where: $\mathrm{a}$ - average acceleration during a cycle, $\mathrm{f}-$ tyre rolling-resistance coefficient, $\mathrm{g}$ - gravitational acceleration, nią przyjmuje ta wielkość podczas jazdy ze zmienną prędkością, zwłaszcza w ruchu miejskim [3,4]. W tych warunkach pracy obciążenie i prędkość obrotowa silnika przypadają bowiem na dolny obszar jego charakterystyki, obejmujący niekorzystnie wysokie wartości jednostkowego zużycia paliwa. Dla odmiany przy zmiennej prędkości sprawność układu przeniesienia napędu jest znacznie wyższa i zmienia się $\mathrm{w}$ dużo węższym przedziale wartości [4]. Stąd sprawność silnika wywiera dominujący wpływ na wartość średnią sprawności napędu. Na przykład dla samochodu osobowego średniej klasy, poruszającego się w cyklu miejskim EPA, wartość średnia sprawności napędu nie przekracza $10 \%$ [4].

Ponieważ profil prędkości decyduje o zmienności zarówno sprawności silnika, jak i układu przeniesienia napędu, zatem sprawność napędu może być wyrażana jedynie wartościa średnia, dla określonego odcinka przebytej drogi $[3,4]$. Sprawność napędu jest złożoną funkcją wielu zmiennych. Funkcja ta zależy nie tylko od profilu prędkości, lecz także od innych czynników, takich jak: nieustalone warunki pracy silnika, czas pracy silnika na biegu jałowym, zmienność i stopniowanie przełożenia oraz straty w układzie przeniesienia napędu [4]. Dla złożonego, wielomodułowego profilu prędkości, o średniej sprawności napędu decydują nie tylko fazy napędzania, lecz także fazy ruchu bez napędu kół oraz postoje, tj. przy zerowej sprawności silnika [3, 4].

Wartość średniej sprawności napędu można określić, wychodząc $\mathrm{z}$ równania ogólnej postaci bilansu energetycznego samochodu (1), gdzie: $\eta$ - średnia sprawność napędu dla kompletnego profilu prędkości, np. cyklu złożonego z wielu modułów, obejmującego również pracę silnika na biegu jałowym, E - energochłonność ruchu, jako suma energii dostarczonej do kół wyłącznie w fazach napędzania cyklu [2 - 4], $\mathrm{G}_{\mathrm{L}}$ - ilość paliwa doprowadzonego do silnika na całym odcinku przebytej drogi, także podczas pracy na biegu jałowym, $\mathrm{W}_{\mathrm{D}}$ - wartość opałowa paliwa.

Natomiast lewa strona równania (1) wyraża energię doprowadzoną do silnika na całej długości przebytej drogi oraz podczas jego pracy na biegu jałowym, w tym również $\mathrm{w}$ trakcie postojów. W praktyce i dla celów porównawczych zużycie paliwa odnosi się do przebytej drogi $Q=G_{L} / L$.

Podobnie do przebytej drogi można odnosić energochłonność ruchu. Dogodnym, w tym przypadku, wskaźnikiem porównawczym jest energochtonność jednostkowa [2 - 4] wyrażana stosunkiem (2).

Wobec tego sprawność napędu wyraża się wzorem (3), gdzie: $\mathrm{L}$ - całkowita droga cyklu, $\mathrm{m}$ - masa pojazdu, Q łączne zużycie paliwa odniesione do długości odcinka przebytej drogi, także podczas pracy na biegu jałowym, ml/m, 1/100 km, $\Phi$ - energochłonność jednostkowa.

Dla profilu prędkości złożonego $\mathrm{z}$ wielu modułów energochłonność jednostkową określa równanie (4) [4], gdzie: $\mathrm{a}$ - średnie przyspieszenie cyklu, $\mathrm{f}$ - współczynnik oporu toczenia, $\mathrm{g}$ - przyspieszenie ziemskie, $\mathrm{K}$ - współczynnik oporu powietrza [4], $\mathrm{L}_{\mathrm{N}}$ - stosunek łącznej drogi faz na- 
$\mathrm{L}_{\mathrm{N}}$ - total distance of powered phases to the total travelled distance ratio, $\mathrm{K}$ - aerodynamic drag coefficient [4], $\vartheta-$ even value of the square of velocity for a completed driving schedule.

The quantities: a, $\mathrm{L}_{\mathrm{N}}, \vartheta$, are exclusively kinematic parameters of the driving schedule, whereas $\mathrm{f}, \mathrm{K}, \mathrm{m}$ are parameters of a vehicle and road. This is the aerodynamic drag coefficient:

$$
\mathrm{K}=0,5 \mathrm{Ac} \mathrm{x}_{\mathrm{X}} \rho
$$

where: A - vehicle frontal area, $\mathrm{c}_{\mathrm{x}}$ - aerodynamic shape coefficient, $\rho-$ air density.

The average acceleration within a cycle is expressed by $\mathrm{s}$ ratio of the kinetic energy summary increase to the mass and distance product.

After reduction of vehicle mass:

$$
\mathrm{a}=\frac{\sum\left(\mathrm{V}_{\mathrm{K}}{ }^{2}-\mathrm{V}_{\mathrm{P}}{ }^{2}\right)}{2 \mathrm{~L}}
$$

where: $\mathrm{V}_{\mathrm{K}}, \mathrm{V}_{\mathrm{P}}$ - final and initial velocity respectively.

The average acceleration within a cycle is a fundamental driving schedule parameter which significantly influences the pędzania do całkowitej drogi cyklu, m - masa pojazdu, $\vartheta$ - wartość średnia kwadratu prędkości dla kompletnego profilu prędkości.

Współczynnik oporu powietrza wynosi (5), gdzie: A powierzchnia czołowa pojazdu, $\mathrm{c}_{\mathrm{x}}$ - współczynnik kształtu, $\rho$-gęstość powietrza.

Wielkości: a, $\mathrm{L}_{\mathrm{N}}, \vartheta$ stanowią wyłącznie parametry kinematyczne cyklu, podczas gdy $\mathrm{f}, \mathrm{K}, \mathrm{L}_{\mathrm{N}}, \mathrm{m}$ są parametrami pojazdu i drogi. Średnie przyspieszenie cyklu wyraża stosunek sumy przyrostów energii kinetycznej do iloczynu masy i drogi, czyli (6), gdzie: $\mathrm{V}_{\mathrm{K}}, \mathrm{V}_{\mathrm{P}}$ odpowiednio: prędkość końcowa i początkowa.

Średnie przyspieszenie cyklu jest podstawowym parametrem profilu prędkości o decydującym wpływie zarówno na energochłonność ruchu, jak i na zużycie paliwa, a więc pośrednio także na sprawność napędu [2 - 4].

\section{Badania}

W tych badaniach wykorzystano dane fabryczne wielu samochodów z silnikami z zapłonem iskrowym oraz z zapłonem samoczynnym. Dane te zawierały również zużycie paliwa, określone w testowych cyklach jezdnych $E C E$ - miejskim oraz jego rozwiniętą wersją, zawierającą segment drogowy, zwaną dalej cyklem mieszanym. Cykle te przyjęto jako reprezentatywne dla jazdy ze zmienną

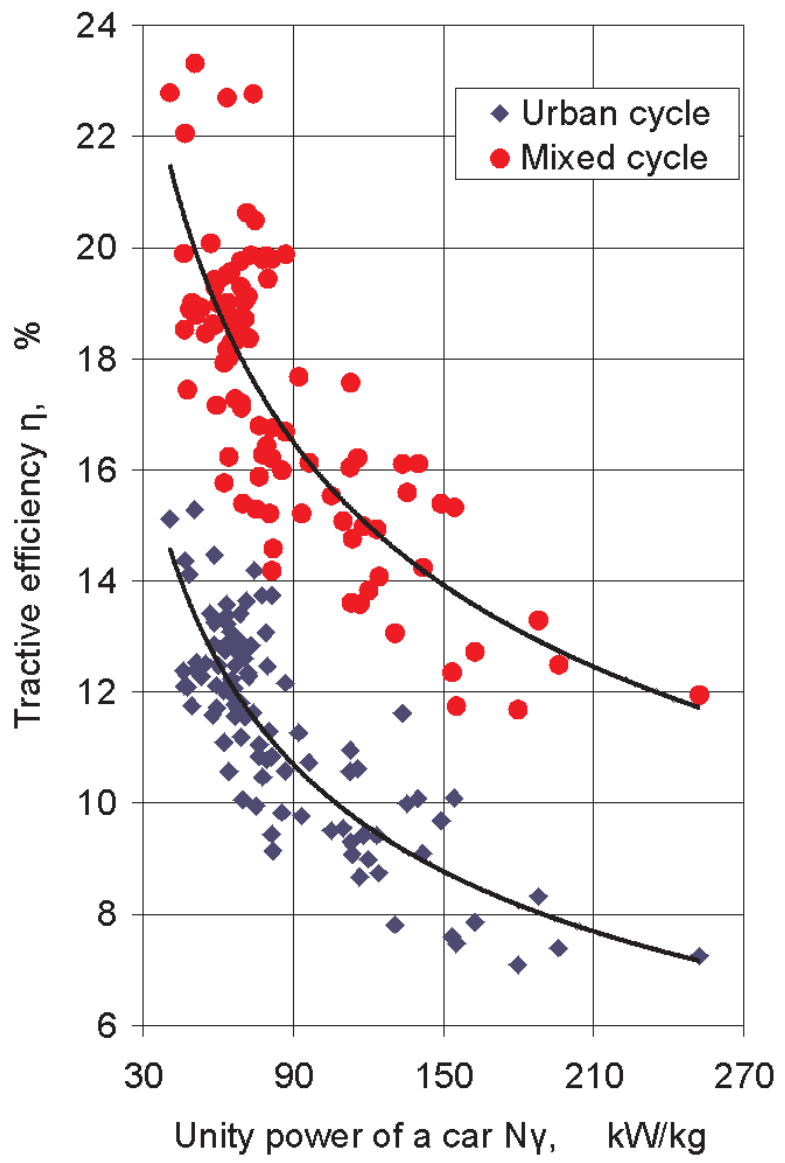

Fig. 1. Influence of: a) mass and b) unit power on the tractive efficiency of a car with SI engine Rys. 1. Wplyw: a) masy i b) mocy jednostkowej na sprawność napędu samochodu z silnikiem o zapłonie iskrowym 

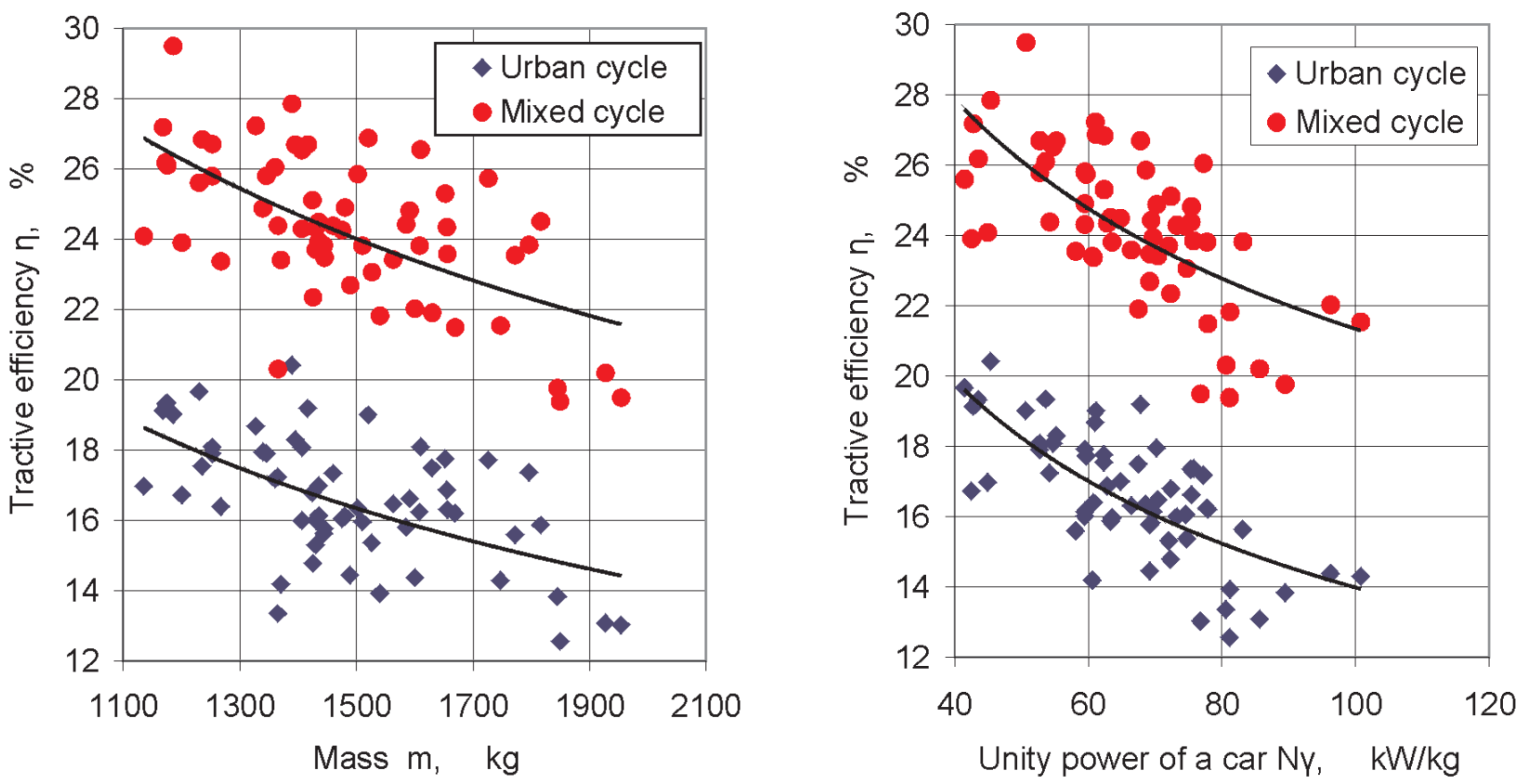

Fig. 2. Influence of: a) mass and b) unit power on the tractive efficiency of a car with Diesel engine

Rys. 2. Wpływ: a) masy i b) mocy jednostkowej na sprawność napędu samochodu z silnikiem o zapłonie samoczynnym

tractive energy consumption as well as the fuel consumption, and therefore, the tractive efficiency, too [2-4].

\section{Investigation}

For the purpose of this study, the factory test data of numerous car motors with spark ignition and self ignition engines were used. These data also include fuel consumption test-bed measurements for the driving cycles ECE - Urban with its extended version containing the road segment, called Mixed Cycle. These cycles were assumed as representative for the driving schedule. The specific tractive energy consumption of each vehicle was calculated on the basis of formulae (4) that introduces parameters determining the motion resistance.

Kinematic parameters of cycles were introduced as a constant also into this equation. Then the tractive efficiency was calculated from equation (3). Some selected results of the research are presented as functions in Figs. 1, 2.

These results of investigation are ploted in graphs of functions: efficiency - mass and efficiency - unit power of the car. Vehicle mass has a decisive impact on the tractive energy consumption and the fuel consumption, especially in the urban traffic $[3,4]$. The unit power of a car is the parameter that expresses the engine effective power to vehicle mass ratio [4]:

$$
\mathrm{N}_{\gamma}=\frac{\mathrm{N}_{\mathrm{e}}}{\mathrm{m}}
$$

where: $\mathrm{N}_{\gamma}$ - vehicle unit power $\mathrm{kW} / \mathrm{kg}, \mathrm{N}_{\mathrm{e}}$ - engine effective power $\mathrm{kW}, \mathrm{m}$ - total vehicle mass, $\mathrm{kg}$.

Each point in these diagrams concerns a different vehicle. Taking their relatively significant scatter of results prędkością. Energochłonność jednostkową każdego z pojazdów obliczano równaniem (4), wprowadzając parametry decydujące o ich oporach ruchu. Do tego równania wprowadzano także, jako stałe, wartości parametrów kinematycznych cykli. Sprawność napędu obliczano wzorem (3). Wybrane wyniki badań przedstawiono na wykresach funkcji: sprawność napędu-masa oraz sprawność napędu - moc jednostkowa pojazdu. Masa pojazdu wywiera bowiem decydujący wpływ na energochłonność ruchu i zużycie paliwa, szczególnie w jeździe miejskiej $[3,4]$. Moc jednostkowa samochodu jest parametrem wyrażanym stosunkiem mocy użytecznej silnika do masy pojazdu (7) [4], gdzie: $\mathrm{N}_{\gamma}$ - moc jednostkowa samochodu, $\mathrm{kW} / \mathrm{kg}, \mathrm{N}_{\mathrm{e}}$ - moc użyteczna silnika, $\mathrm{kW}, \mathrm{m}$ - masa całkowita samochodu, $\mathrm{kg}$.

Wybrane wyniki przeprowadzonych badań sprawności napędu przedstawiono na rys. 1 i 2 .

Każdy z punktów na tych wykresach dotyczy innego pojazdu. Wobec ich stosunkowo znacznego rozrzutu określono przybliżone linie trendu, stosując odpowiednio: funkcję wykładniczą i logarytmiczną. Ponieważ badania obejmowały symulację ruchu różnych samochodów w identycznych cyklach, zatem parametry profilu prędkości nie decydują o rozrzucie punktów na wykresach. Natomiast rozrzut ten zależy z jednej strony od zróżnicowanych parametrów badanych samochodów decydujących o oporach ruchu, z drugiej zaś od właściwości silnika i zmienności parametrów jego pracy, generowanych zmiennością obciążenia i prędkości.

Przedstawione wykresy obrazują znaczenie masy pojazdu oraz mocy silnika i jego sprawności użytecznej, jako czynników o największym wpływie na sprawność napędu. Należy jednak uwzględnić to, że badana wielkość jest funk- 
into account, the approximate trend lines were determined with the use of an exponential and logarithmic function respectively. The driving schedule parameters do not account for the scatter of points in the diagrams due to the fact that this study included a simulation with various vehicles driven in identical cycles. Nevertheless, the scatter of results is the outcome of different parameters defining the vehicle motion resistance on the one hand, and engine properties with operating parameters variability on the other.

The presented graphs show the importance of vehicle mass, engine power and effective efficiency as factors exerting the greatest influence on the tractive efficiency. However, it should be noticed that the tested quantity is a function of several variables which are not all included in this study. It may be the main cause of the scatter of the test results.

The tractive efficiency in the urban cycle is much lower in all diagrams. The average acceleration in the driving schedule is the component with the highest value in equation (4). This quantity is directly proportional to the kinetic energy summary increase and reaches maximum value in the urban traffic because of numerous stop and go modules [2, 3]. Frequent velocity changes induce unstable conditions, which together with transmission ratio changes, decrease engine effective efficiency. Moreover, numerous braking phases and stops appear in urban cycles, while engine effective efficiency is zero. On the contrary, an additional longer segment simulating highway driving with constant speed-phases without stopping occur in the mixed cycles [4].

The tractive efficiency decrease with car unit-power increase is a consequence of limited velocity levels in test cycles. Followingly, the power excess above its requirement on the drive wheels at moderate speed increases together with the engine maximal power. The outcome of this correlation is a significant decrease in the engine effective efficiency [4].

The presented graphs clearly show higher tractive efficiency in the case of a car with self ignition engine than with spark ignition due to generally higher effective efficiency of diesel engines. Thus a considerable difference in position of curves for both types of engines confirms indirect the predominant influence of the engine effective efficiency on the car tractive efficiency.

In spite of the significant scatter of points in the graphs, it is possible to estimate the approximate tractive efficiency ranges with the use of trend lines.

The influence of car mass in the urban and mixed cycle respectively:

- spark ignition engine $=0.09-0.14$ and $=0,14-0,21$, - self-ignition engine $=0.14-0.19$ and $=0.22-0.27$.

The influence of the car unit power in the urban and mixed cycle respectively:

- spark ignition engine $\eta=0.07-0.15$ and $\eta=0.12-$ 0.21 ,

- self-ignition engine $\eta=0.14-0.20$ and $\eta=0.21-0.28$. cją wielu zmiennych, z których część pominięto, co stanowi główną przyczynę rozrzutu punktów na wykresach.

Wszystkie wykresy wykazują zdecydowanie niższą sprawność napędu w cyklu miejskim. Składnikiem równania (4) o najwyższej wartości, jest średnie przyspieszenie cyklu jako wielkość wprost proporcjonalna do sumy przyrostów energii kinetycznej samochodu, która jest największa w cyklu miejskim, a to ze względu na liczne moduły stop and go [3]. Częstym zmianom prędkości samochodu towarzyszą bowiem nieustalone warunki pracy silnika, które łącznie ze zmianami przełożenia generują obniżenie jego sprawności. Ponadto w jeździe miejskiej występują liczne fazy hamowania oraz postoje, w których sprawność silnika jest zerowa, co generuje również zerową sprawność napędu. Natomiast w cyklu mieszanym występuje dodatkowy dłuższy segment, symulujący jazdę pozamiejską, bez postojów i z fazami stałej prędkości [4].

Spadek wartości sprawności napędu, w miarę wzrostu mocy jednostkowej samochodu, jest następstwem ograniczonego poziomu prędkości badanych cykli. Wtedy bowiem ze wzrostem wartości mocy maksymalnej silnika zainstalowanego w samochodzie wzrasta również wartość nadwyżki mocy, ponad jej zapotrzebowanie dla jazdy z umiarkowaną prędkością. Wtedy, w ogólnym przypadku, parametry pracy silnika przypadają na coraz niższy obszar jego charakterystyki. Następstwem tego jest znaczący spadek wartości sprawności użytecznej silnika [4]. Przedstawione wykresy wskazują jednoznacznie wyższą sprawność napędu samochodów z silnikami z zapłonem samoczynnym. Jest to wynikiem ogólnie wyższej sprawności użytecznej silników z zapłonem samoczynnym. To wyraźne zróżnicowanie położenia krzywych dla obu typów silników potwierdza decydujący wpływ sprawności użytecznej silnika na sprawność napędu samochodu.

Mimo znacznego rozrzutu punktów na wykresach można, wykorzystując linie trendów, oszacować w przybliżeniu przeciętne zakresy wartości sprawności.

Wpływ masy - odpowiednio w cyklu miejskim i mieszanym:

- silnik ZI $=0,09-0,14$ oraz $=0,14-0,21$,

- silnik ZS $=0,14-0,19$ oraz $=0,22-0,27$.

Wpływ mocy jednostkowej - odpowiednio w cyklu miejskim i mieszanym:

- silnik ZI $=0,07-0,15$ oraz $=0,12-0,21$,

- silnik ZS $=0,14-0,20$ oraz $=0,21-0,28$.

\section{Podsumowanie}

Przedstawione wyniki badań obrazują zależność sprawności napędu od tych podstawowych parametrów samochodu i silnika, które wywierają największy wpływ na zużycie paliwa przy zmiennej prędkości. Ze względu na pominięcie wpływu mniej istotnych czynników, wyniki te mają charakter przybliżony. Mimo to umożliwiły one dokonanie oceny porównawczej przedziałów wartości i przebiegu badanych funkcji, dla dwóch cykli testowych i dwóch rodzajów silnika. 


\section{Summary}

Presented results of the investigations show that the tractive efficiency depends on main car and engine parameters which have an utmost influence on the fuel consumption at a variable speed. Due to the fact that some less important factors were neglected, presented results are approximate. Nevertheless, they enabled a comparative analysis of value ranges and courses of studied functions for two tested cycles and two types of engines.

Both correlations studied in this article are represented by a nonlinear function decreasing with the increase in vehicle mass and engine power. The significant influence of the driving schedule is confirmed by the higher tractive efficiency in the road traffic due to a higher average car speed and longer phases at a constant speed. Then the engine works in more favorable conditions, longer time with steady load and shorter at idle.

However, the engine effective efficiency decreases with the maximal engine power increase, particularly in the urban traffic [4]. A comparative analysis of the graphs in Figure 1 and 2 clearly confirm higher tractive efficiency of cars with diesel engine mainly because of their higher effective efficiency in general. The difference between cars with different engines is independent from the realized driving schedule.

An important advantage of the presented testing method is the possibility to determine the engine efficiency both in simulated and real operating conditions of a vehicle. Moreover, this method allows a comparison of the car effective efficiency with different engines installed in the same vehicle, both in stand tests and during road tests in given traffic conditions [4, 5]. For different engines installed in the same vehicle, the design and efficiency of a powertrain system are not substantially changeable. In addition, the efficiency variability occurs within a narrow range of values [4]. Thus, the powertrain system efficiency has a minor influence on the comparative analysis of different engines.
Obie badane zależności przedstawiają funkcję nieliniową, malejącą zarówno ze wzrostem masy pojazdu jak i mocy silnika. Przedstawione wykresy potwierdzają znaczący wpływ profilu prędkości, czego dowodem jest odpowiednio wyższa sprawność napędu w ruchu drogowym. Jest to spowodowane wyższą prędkością średnią samochodu i dłuższymi fazami ruchu ze stałą prędkością. Wtedy silnik pracuje w korzystniejszym obszarze charakterystyki, dłużej w stanie ustalonym i krótko na biegu jałowym. Natomiast w miarę wzrostu mocy silnika, szczególnie w ruchu miejskim, jego obciążenie przypada na coraz to niższy obszar charakterystyki obejmujący malejące wartości sprawności użytecznej [4]. Z porównania wykresów na rys. 1 i 2 wynika potwierdzenie wyraźnie wyższej sprawności napędu samochodów z silnikami o zapłonie samoczynnym, głównie względu na ich wyższą sprawność użyteczną. To zróżnicowanie jest niezależne od realizowanego profilu prędkości.

Istotną zaletą przyjętej metody jest możliwość przybliżonego określania sprawności użytecznej silnika, zarówno w symulowanych jak i w rzeczywistych warunkach ruchu pojazdu. Można zatem porównywać sprawność użyteczną różnych wersji silnika instalowanego w jednym pojeździe: albo na stanowisku dynamometrycznym albo podczas testów drogowych w określonych warunkach ruchu $[4,5]$. Dla różnych wersji silników zainstalowanych $\mathrm{w}$ danym pojeździe konstrukcja i sprawność układu napędowego nie ulega bowiem zasadniczym zmianom. Ponadto zmienność tej sprawności mieści się w wąskim przedziale wartości [4]. Zatem sprawność układu przeniesienia napędu nie wywiera zasadniczego wpływu na jakość oceny porównawczej sprawności użytecznej różnych silników.

Paper reviewed/Artykut recenzowany

\section{Bibliography/Literatura}

[1] Mitschke M.: Motor-Kennungswanler-Kraftstoffverbrauch. Automobiltechnishe Zeitsschrift 1981, nr 1.

[2] Siłka W.: Analiza wpływu parametrów cyklu jezdnego na energochłonność ruchu samochodu. Teka Komisji NaukowoProblemowej Motoryzacji PAN oddz. w Krakowie, Z. 14. Monografia 2, Kraków 1998.

[3] Siłka W.: Parameters influencing energy properties of the car driving in urban cycles. Archives of transport, v. 10 issue 3-4. PAN Warszawa 1999.

[4] Siłka W.: Teoria ruchu samochodu, WNT, Warszawa 2002.

[5] Siłka W., Hetmańczyk I.: Analiza wpływu stylu jazdy na energochłonność ruchu samochodu. Teka Komisji NaukowoProblemowej Motoryzacji PAN oddz. w Krakowie, nr 33-34, Kraków 2008.
[6] Sovran G., Bohn M.: Formulae for the Tractive-Energy Requirements of Vehicles Driving the EPA Schedules. SAE paper 1981, nr 810184 .

Mr. Wojciech Siłka, DSc., DEng. - Professor in the Faculty of Mechanical Engineering at Opole University of Technology.

Dr hab. inż. Wojciech Sitka - profesor na Wydziale Mechanicznym Politechniki Opolskiej. e-mail:w.silka@po.opole.pl

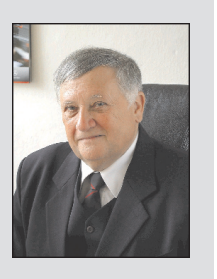

